\title{
Short communication: Partial replacement of ground corn with algae meal in a dairy cow diet: Milk yield and composition, nutrient digestibility, and metabolic profile
}

\author{
G. G. da Silva, ${ }^{*}$ E. Ferreira de Jesus, ${ }^{*}$ C. S. Takiya, ${ }^{*}$ T. A. Del Valle, ${ }^{*}$ T. H. da Silva, ${ }^{*}$ T. H. A. Vendramini, ${ }^{*}$ \\ Esther J. Yu,† and F. P. Rennó*1 \\ *Department of Animal Nutrition and Production, University of Sao Paulo, Pirassununga 13635-900, Brazil \\ †TerraVia Holdings Inc., 225 Gateway Blvd., South San Francisco, CA 94080
}

\begin{abstract}
This study was undertaken to evaluate the effects of partially replacing dietary ground corn with a microalgae meal from Prototheca moriformis (composed of deoiled microalgae and soyhulls) on milk yield and composition, nutrient intake, total-tract apparent digestibility, and blood profile of lactating dairy cows. Twenty multiparous Holstein cows $(57.7 \pm 49.4$ d in milk, 25.3 \pm 5.3 of milk yield, and $590 \pm 71 \mathrm{~kg}$ of live weight at the start of experiment, mean \pm standard deviation) were used in a cross-over design experiment, with 21-d periods. Diets were no microalgae meal $(\mathrm{CON})$ or 91.8 $\mathrm{g} / \mathrm{kg}$ of microalgae meal partially replacing dietary ground corn (ALG). Cows showed similar milk yield and composition. The $3.5 \%$ fat-corrected milk production was $30.2 \pm 1.34 \mathrm{~kg} / \mathrm{d}$ for $\mathrm{CON}$ and $31.1 \pm 1.42$ $\mathrm{kg} / \mathrm{d}$ for ALG. Despite cows having similar dry matter intake, ALG increased neutral detergent fiber and ether extract intake. In addition, cows fed ALG exhibited higher ether extract digestibility. No differences were detected in glucose, urea, amino-aspartate transferase, and gamma-glutamyl transferase blood concentrations. Feeding ALG increased the total cholesterol and highdensity lipoprotein in blood compared with $\mathrm{CON}$. The microalgae meal may partially replace ground corn in diets of lactating cows without impairing the animal's performance.
\end{abstract}

Key words: coproduct, energy source, feedstuffs, soyhulls

\section{Short Communication}

The large-scale production of heterotrophic microalgae (Prototheca moriformis) has been supported by recent advances in technology. These microalgae are genetically modified to produce various types of oil or

Received June 1, 2016.

Accepted July 2, 2016.

${ }^{1}$ Corresponding author: francisco.renno@usp.br more oil (or both) than their wild-type counterparts, which are then used for food, personal care, and other animal nutrition applications. Previously, the deoiled extract (dry cell wall) was considered a waste product and burned. Now, a dry, deoiled, milled microalgae coproduct has been developed by researchers as a feed for ruminants. Based on the deoiled microalgae composition, Van Emon et al. (2015) suggested that a blend of microalgae and soyhulls could replace corn in diets for beef cattle. These authors combined these ingredients to form a microalgae meal (ALG) consisting of $570 \mathrm{~g} /$ $\mathrm{kg}$ of microalgae and then evaluated this product up to $450 \mathrm{~g} / \mathrm{kg}$ of diet DM on performance of growing steers. Positive effects were found in DMI and in the ADG of animals, supporting the viability of ALG as a feedstuff for ruminants. This particular microalgae meal is a novel feedstuff, and to our knowledge no experiment has been published evaluating its inclusion in dairy cow diets, although there have been studies using meal derived from other algal species (Franklin et al., 1999; Moate et al., 2013). Because of the rising global population, the USDA estimated the demand for corn to climb to 327 million metric tonnes by 2022 (Westcott and Trostle, 2014). A large portion of the diets of lactating cows consists of cereals, especially ground corn. Because corn prices fluctuate throughout the year, replacing corn with by-products may reduce feed costs, decrease reliability on corn feedstocks, and increase dairy profitability. The aim of this study was to determine the effects of the partial replacement of ground corn with ALG on milk yield and composition, nutrient digestibility, and blood profile of lactating dairy cows. Our hypothesis was that ALG replacing ground corn would not affect the cow's performance and blood profile.

This experiment was carried out with permission of the Bioethics Committee of School of Veterinary Medicine and Animal Science, University of Sao Paulo. Twenty multiparous Holstein cows (57.7 \pm 49.4 DIM, $25.3 \pm 5.3$ of milk yield, and $590 \pm 71 \mathrm{~kg}$ of live weight at the start of experiment, mean $\pm \mathrm{SD}$ ) were selected 
from the Dairy Cattle Research Laboratory (Pirassununga, Brazil) herd for this experiment. Cows were housed in individual pens $\left(17.5 \mathrm{~m}^{2}\right.$ of area), containing sand bedding, feed bunks, and forced ventilation. Animals were randomly assigned to the treatment sequence in a cross-over experimental design. Diets were formulated according to NRC (2001; Table 1), supplied twice daily (0700 and $1330 \mathrm{~h}$ ) as a TMR, and consisted of a typical diet for lactating cow with no microalgae meal $(\mathbf{C O N})$ and inclusion of $91.7 \mathrm{~g} / \mathrm{kg}$ of ALG. Microalgae meal (TerraVia Holdings Inc., South San Francisco, $\mathrm{CA}$ ) is a combination of $570 \mathrm{~g} / \mathrm{kg}$ of deoiled microalgae bodies (from Prototheca moriformis) and $430 \mathrm{~g} / \mathrm{kg}$ of soyhulls and was used to partially replace $342 \mathrm{~g} / \mathrm{kg}$ of ground corn from CON. During the production process, the microalgae undergoes 2 separate inactivation steps, heat treatment and drying; therefore, the ALG contains no viable microalgae. Trial periods lasted for $21 \mathrm{~d}$, of which the first $14 \mathrm{~d}$ were to allow diet adaptation and $\mathrm{d}$ 15 to 21 were used for sampling and statistical analysis. Animals were individually fed daily to obtain refusals between 5 and $10 \%$ of feed offered. Wet content of corn silage was determined weekly and dietary adjustments were made when necessary.

Samples of corn silage and concentrate ingredients were collected weekly and analyzed for DM (method 930.15), $\mathrm{CP}(\mathrm{CP}=\mathrm{N} \times 6.25$; method 984.13), and ether extract (EE; method 920.39) according to AOAC International (2000). Ash was determined after $4 \mathrm{~h}$ at $600^{\circ} \mathrm{C}$ in a muffle furnace. Neutral detergent fiber, $\mathrm{ADF}$, and lignin were determined in a fiber analyzer (TE-149 fiber analyzer, Tecnal Equipment for Laboratory Inc., Piracicaba, Brazil) according to Van Soest et al. (1991) using a amylase and no sodium sulfide. Nonfiber carbohydrate was estimated according to Hall (2000) as follows: NFC $=100-[(\mathrm{CP}-\mathrm{CP}$ from urea + urea $)+\mathrm{NDF}+\mathrm{EE}+\mathrm{ash}]$, with all values expressed as a percentage.

Animals were milked twice daily (0600 and $1530 \mathrm{~h}$ ) and milk production was electronically measured (Alpro, DeLaval, Tumba, Sweden). Milk sampling was performed on d 15, 16, and 17 of each period and analyzed for fat, protein, and lactose by infrared method (Lactoscan, Sao Paulo, Brazil). Fat-corrected milk yield was calculated according to Sklan et al. (1992), as follows: FCM $(\mathrm{kg} / \mathrm{d})=$ milk yield $(\mathrm{kg} / \mathrm{d}) \times(0.432+0.163 \times$ milk fat percentage).

Feed intake was recorded daily and samples of refusals were collected during the 7 -d sampling period and composited (on a wet basis) to form a representative sample for each cow and each period. Feces were collected directly from the rectum of cows on d 18, 19, and 20 of each period after each milking. Fecal samples were also composited (on wet-basis) to form representative samples. Samples of dietary ingredients, refusals, and feces were dried in a forced-air oven at $55^{\circ} \mathrm{C}$ for $72 \mathrm{~h}$ and ground in a Wiley mill to pass through 2 -mm and 1-mm screens. All samples were analyzed for DM, ash, $\mathrm{CP}, \mathrm{EE}$, and NDF, as previously described. Nutrient total apparent digestibility was determined based on daily fecal excretion using indigestible NDF (iNDF) as an internal marker. Ground samples (2-mm particle size) of ingredients, refusals, and feces were incubated using nonwoven textile bags $(5 \times 5 \mathrm{~cm}, 50 \mu \mathrm{m}$ pore size; $20 \mathrm{mg}$ of $\mathrm{DM} / \mathrm{cm}^{2}$ ) in the rumen of 2 Holstein cows adapted to the CON diet of this experiment. After 288 $\mathrm{h}$, bags were removed from the rumen and washed in running tap water and analyzed for NDF concentration (Casali et al., 2008).

Table 1. Ingredients and chemical composition of experimental diets (g/kg of DM, unless otherwise stated)

\begin{tabular}{lcc}
\hline & \multicolumn{2}{c}{ Diet $^{1}$} \\
\cline { 2 - 3 } Item & CON & ALG \\
\hline Ingredient & & \\
Corn silage & 501 & 501 \\
Ground corn & 269 & 177 \\
Soybean meal & 113 & 113 \\
Whole raw soybean & 80.1 & 80.1 \\
Microalgae meal ${ }^{2}$ & 16.0 & 91.7 \\
Minerals and vitamins & & 16.0 \\
Sodium bicarbonate & 9.00 & 9.00 \\
Dicalcium phosphate & 4.60 & 4.60 \\
Urea & 3.80 & 3.80 \\
Limestone & 1.40 & 1.40 \\
Magnesium oxide & 1.10 & 1.10 \\
Salt & 0.90 & 0.90 \\
Ammonium sulfate & 0.50 & 0.50 \\
Chemical & & \\
DM (g/kg) & 598 & 602 \\
OM & 926 & 934 \\
NFC & 389 & 376 \\
NDF & \\
ADF & 333 & 345 \\
iNDF & 152 & 169 \\
Lignin & 80.7 & 84.4 \\
CP & 30.4 & 30.9 \\
Ether extract & 166 & 163 \\
Ash & 37.6 & 39.5 \\
\hline CON no microalgae & 74.1 & 76.3 \\
\hline
\end{tabular}

${ }^{1} \mathrm{CON}=$ no microalgae meal; ALG $=$ microalgae meal replacing $34.2 \%$ of ground corn.

${ }^{2}$ Contained $57 \%$ of deoiled microalgae bodies and $43 \%$ of soyhulls. Composition: $971 \mathrm{~g} / \mathrm{kg}$ of DM, $975 \mathrm{~g} / \mathrm{kg}$ of OM, $274 \mathrm{~g} / \mathrm{kg}$ of NDF, 77.9 $\mathrm{g} / \mathrm{kg}$ of $\mathrm{CP}, 55.7 \mathrm{~g} / \mathrm{kg}$ of ether extract.

${ }^{3}$ Contained per kilogram of product: $88.0 \mathrm{~g}$ of $\mathrm{Ca}, 42.0 \mathrm{~g}$ of $\mathrm{P}, 18.0 \mathrm{~g}$ of S, $45.0 \mathrm{~g}$ of $\mathrm{Mg}, 123.0 \mathrm{~g}$ of Na, $14.0 \mathrm{mg}$ of $\mathrm{Co}, 500.0 \mathrm{mg}$ of $\mathrm{Cu}, 20.0$ $\mathrm{mg}$ of $\mathrm{Cr}, 1,050.0 \mathrm{mg}$ of Fe, $28.0 \mathrm{mg}$ of I, 1,400.0 mg of Mn, $18.0 \mathrm{mg}$ of Se, 2,800.0 mg of Zn, $80.0 \mathrm{mg}$ of biotin, 200,000.00 IU of vitamin A, 40,000.00 IU of vitamin D, and 1,200.00 IU of vitamin E.

${ }^{4}$ Nonfiber carbohydrate estimated according to Hall (2000) in which $\mathrm{NFC}=1,000-[(\mathrm{CP}-\mathrm{CP}$ from urea + urea $)+\mathrm{NDF}+$ ether extract + ash]; all values expressed as grams per kilogram of DM.

${ }^{5}$ Indigestible NDF. 
Table 2. Effects on milk yield and composition by partially replacing ground corn with microalgae meal in the dairy cow diet

\begin{tabular}{lccccc}
\hline & \multicolumn{3}{c}{ Diet $^{1}$} & & \\
\cline { 2 - 3 } Item & CON & ALG & Mean & SEM & P-value \\
\hline Yield $(\mathrm{kg} / \mathrm{d})$ & & & & & \\
Milk & 27.3 & 27.7 & 27.5 & 0.922 & 0.492 \\
$3.5 \% \mathrm{FCM}^{2}$ & 30.2 & 31.1 & 30.6 & 0.970 & 0.255 \\
Fat & 1.13 & 1.18 & 1.15 & 0.040 & 0.237 \\
Protein & 0.81 & 0.82 & 0.81 & 0.026 & 0.669 \\
Lactose & 1.21 & 1.22 & 1.22 & 0.038 & 0.739 \\
Composition $(\mathrm{g} / \mathrm{kg})$ & & & & & \\
Fat & 42.1 & 43.2 & 42.63 & 1.007 & 0.246 \\
Protein & 29.9 & 29.7 & 29.84 & 0.239 & 0.192 \\
Lactose & 44.8 & 44.6 & 44.71 & 0.356 & 0.221 \\
\hline
\end{tabular}

${ }^{1} \mathrm{CON}=$ no microalgae meal; $\mathrm{ALG}=$ microalgae meal replacing $34.2 \%$ of ground corn.

${ }^{2}$ Calculated according to Sklan et al. (1992), in which FCM $(\mathrm{kg} / \mathrm{d})=$ milk yield $(\mathrm{kg} / \mathrm{d}) \times(0.432+0.163 \times$ milk fat percentage).

Digestibility of DM

$$
=100-\left[100 \times\left(\frac{\% \text { iNDF intake }}{\% \text { iNDF in feces }}\right)\right] \text {. }
$$

Digestibility of nutrient $=100-$ $\left[100 \times\left(\frac{\% \text { iNDF intake }}{\% \text { iNDF in feces }}\right) \times\left(\frac{\% \text { nutrient in feces }}{\% \text { nutrient intake }}\right)\right]$.

Blood samples were collected on d 21 of each period from coccygeal vessels before the morning feeding, and analyzed for glucose, total protein, albumin, urea, triglycerides, total cholesterol, high-density lipoprotein (HDL), and hepatic enzymes by colorimetric method using commercial kits (Bioclin, Belo Horizonte, Brazil) and reading performed by a semi-automatic biochemistry analyzer (SBA-200, CELM, Sao Caetano do Sul, Brazil).

Data were submitted to ANOVA using the PROC MIXED SAS 9.4 (Statistical Analysis for Windows, SAS Institute Inc., Cary, NC) according to the following model:

$$
\mathrm{y}_{i j k}=\mu+\alpha_{i}+\beta_{j}+\gamma_{k}+\mathrm{e}_{i j k},
$$

where $\mathrm{y}_{i j k}$ represents the observation on animal $k$ given treatment $i$ at period $j ; \mu$ is the overall mean; $\alpha_{i}$ represents the fixed effect of the $i$ th treatment ( $i=1$ to 2 ); $\beta_{j}$ represents the fixed effect of the $j$ th period ( $j=1$ to 2 ); $\gamma_{k}$ represents the random effect of animal ( $k=1$ to 20 ); and $\mathrm{e}_{i j k}$ represents the random error associated with each observation. Means were adjusted by LSMEANS, and degrees of freedom were calculated by the Kenward and Roger (1997) method. The significance level was set at $P \leq 0.05$.
Partially replacing ground corn by ALG did not ( $P$ $\geq 0.192$ ) affect milk yield and composition (Table 2 ). The $3.5 \%$ FCM production did not differ between diets and was $30.2 \pm 1.34 \mathrm{~kg} / \mathrm{d}$ for CON and $31.1 \pm 1.42$ $\mathrm{kg} / \mathrm{d}$ for ALG. Despite no observed differences for milk production, cows fed ALG showed higher $(P \leq 0.012)$ $\mathrm{NDF}$, iNDF, and EE intake (kg/d) compared with those fed CON (Table 3). The NDF intake relative to the live weight $(\mathrm{g} / \mathrm{kg}$ of live weight) also increased $(P$ $=0.010)$ when cows were supplied ALG. Ether extract digestibility was higher $(P=0.002)$ in cows fed ALG compared with those fed CON. Cows fed ALG had higher total cholesterol and HDL blood concentrations compared with CON (Table 4). Hepatic enzymes were not affected $(P \geq 0.107)$ by ALG supply.

Although the DMI was not influenced by experimental diets, NDF and EE intake were increased when ALG was fed to cows. These effects can be related to the microalgae meal composition, which slightly increased dietary NDF and EE of ALG. In contrast with our findings, Van Emon et al. (2015) found a linear increase of DMI when growing beef steers were fed with microalgae meal up to $450 \mathrm{~g} / \mathrm{kg}$ of DM partially replacing wet corn gluten feed. Stokes et al. (2015) evaluated the addition of microalgae meal up to $450 \mathrm{~g} / \mathrm{kg}$ DM in place of corn on DMI and nutrient digestibility of wethers and also reported a linear increase of DMI. The differences among results are related to the inclusion of microalgae meal and NFC content of diets. Whereas in our study the microalgae meal inclusion was $91.7 \mathrm{~g} / \mathrm{kg}$ of diet DM, the minimum inclusion of this coproduct in the other trials was $150 \mathrm{~g} / \mathrm{kg}$, and the dietary NFC content in the current experiment was decreased by $11.3 \mathrm{~g} / \mathrm{kg}$ of DM when adding microalgae meal, whereas the other trials exhibited a decrease in dietary NFC content up to $143.3 \mathrm{~g} / \mathrm{kg}$. Changes in NFC 
Table 3. Effects on nutrient intake and total-tract apparent digestibility by partially replacing ground corn with microalgae meal in the dairy cow diet

\begin{tabular}{|c|c|c|c|c|c|}
\hline \multirow[b]{2}{*}{ Item } & \multicolumn{2}{|c|}{$\operatorname{Diet}^{1}$} & \multirow[b]{2}{*}{ Mean } & \multirow[b]{2}{*}{ SEM } & \multirow[b]{2}{*}{$P$-value } \\
\hline & $\mathrm{CON}$ & ALG & & & \\
\hline \multicolumn{6}{|l|}{$\overline{\text { Intake }(\mathrm{kg} / \mathrm{d})}$} \\
\hline DM & 22.0 & 22.6 & 22.3 & 0.687 & 0.275 \\
\hline $\mathrm{OM}$ & 20.4 & 20.8 & 20.6 & 0.635 & 0.338 \\
\hline $\mathrm{NFC}^{2}$ & 10.2 & 10.3 & 10.3 & 0.315 & 0.515 \\
\hline $\mathrm{NDF}$ & 7.18 & 7.69 & 7.44 & 0.237 & 0.012 \\
\hline $\mathrm{CP}$ & 3.76 & 3.78 & 3.77 & 0.114 & 0.794 \\
\hline Ether extract & 0.86 & 0.93 & 0.90 & 0.027 & 0.002 \\
\hline \multicolumn{6}{|c|}{ Intake ( $\mathrm{g} / \mathrm{kg}$ of live weight) } \\
\hline DM & 37.3 & 38.2 & 37.76 & 1.071 & 0.292 \\
\hline NDF & 12.2 & 12.9 & 12.59 & 0.363 & 0.010 \\
\hline \multicolumn{6}{|c|}{ Digestibility coefficient } \\
\hline $\mathrm{DM}$ & 0.737 & 0.736 & 0.737 & 0.0060 & 0.941 \\
\hline $\mathrm{OM}$ & 0.760 & 0.758 & 0.759 & 0.0071 & 0.842 \\
\hline $\mathrm{NDF}$ & 0.668 & 0.666 & 0.667 & 0.0070 & 0.835 \\
\hline $\mathrm{CP}$ & 0.737 & 0.723 & 0.730 & 0.0084 & 0.336 \\
\hline Ether extract & 0.830 & 0.884 & 0.857 & 0.0090 & 0.002 \\
\hline
\end{tabular}

${ }^{1} \mathrm{CON}=$ no microalgae meal; ALG = microalgae meal replacing $34.2 \%$ of ground corn.

${ }^{2}$ Nonfiber carbohydrate estimated according to Hall (2000), in which NFC $=1,000-[(\mathrm{CP}-\mathrm{CP}$ from urea + urea) + NDF + ether extract + ash]; all values expressed as $\mathrm{g} / \mathrm{kg}$ of DM.

content results in differences of dietary energy density, altering DMI of animals. In addition, other authors reported linear decrease of DMI when soyhulls replaced corn in lactating dairy cow diets (Ipharraguerre et al., 2002). However, our findings agree with several experiments as described by Ipharraguerre and Clark (2003) which analyzed data from 15 studies that evaluated diets containing soyhulls, and 13 of these studies did not report differences on DMI between control diets and those containing soyhulls.

In the current experiment, microalgae meal increased the EE digestibility compared with CON. Stokes et al.
(2015) reported a linear increase of DMI and of nutrient digestibility, including DM, NDF, EE, nitrogen, and NFC, when wethers were fed microalgae meal. Although the aim of algae production is to extract oil, residual oil remains in the deoiled microalgae, increasing the EE of diets and consequently increasing $\mathrm{EE}$ digestibility. Wu et al. (1991) have described improvement on fat digestibility when increasing $30 \mathrm{~g} / \mathrm{kg}$ of dietary EE. None of the experiments evaluating microalgae meal cited above evaluated blood metabolites. In the current experiment, we observed an increase of total cholesterol and HDL cholesterol concentration in blood. The

Table 4. Effects on blood profile $(\mathrm{mg} / \mathrm{dL}$, unless otherwise stated) by partially replacing ground corn with microalgae meal in dairy cow diet

\begin{tabular}{|c|c|c|c|c|c|}
\hline \multirow[b]{2}{*}{ Item } & \multicolumn{2}{|c|}{$\operatorname{Diet}^{1}$} & \multirow[b]{2}{*}{ Mean } & \multirow[b]{2}{*}{ SEM } & \multirow[b]{2}{*}{$P$-value } \\
\hline & $\mathrm{CON}$ & ALG & & & \\
\hline Glucose & 78.7 & 78.4 & 78.6 & 1.658 & 0.912 \\
\hline Total protein & 8.39 & 8.57 & 8.48 & 0.125 & 0.221 \\
\hline Albumin & 3.19 & 3.22 & 3.20 & 0.067 & 0.646 \\
\hline Creatinine & 1.27 & 1.31 & 1.29 & 0.021 & 0.184 \\
\hline Urea & 39.3 & 36.2 & 37.7 & 0.903 & 0.056 \\
\hline Triglycerides & 15.6 & 15.8 & 15.7 & 0.455 & 0.787 \\
\hline \multicolumn{6}{|l|}{ Cholesterol } \\
\hline Total $^{2}$ & 152 & 175 & 163 & 5.828 & $<0.001$ \\
\hline HDL & 123 & 134 & 129 & 3.806 & 0.037 \\
\hline \multicolumn{6}{|c|}{ Hepatic enzymes $^{3}$ (IU/L) } \\
\hline AST & 74.40 & 76.25 & 75.33 & 3.095 & 0.644 \\
\hline GGT & 27.95 & 24.70 & 26.33 & 1.991 & 0.107 \\
\hline
\end{tabular}

${ }^{1} \mathrm{CON}=$ no microalgae meal; $\mathrm{ALG}=$ microalgae meal replacing $34.2 \%$ of ground corn .

${ }^{2}$ Total cholesterol is composed of high-density lipoprotein (HDL), low-density lipoprotein (LDL), and very low density lipoprotein (VLDL).

${ }^{3}$ Hepatic enzymes consist of aspartate aminotransferase (AST) and gamma-glutamyl transferase (GGT). 
increase of total cholesterol is related to the increased EE digestibility when feeding ALG. The absorption of fat increases the lipoprotein cholesterol production by the intestine, which is the major site of cholesterol synthesis in ruminants (Noble, 1981). High-density lipoprotein comprises almost $80 \%$ of total lipoproteins in blood (Grummer and Carroll, 1988), and thus, the increased total cholesterol in blood appears to be due to the HDL cholesterol (Puppione et al., 1982).

Certain algal species can accumulate heavy metals at high concentrations, and currently no regulation for heavy metals concentration in microalgal products exists (Becker, 2004). The microalgae meal used in the current experiment does not appear to have any toxic effect because the concentration of hepatic enzymes in blood, specifically aspartate-amino transferase and gamma-glutamyl transferase that are associated with liver damage caused by toxic substances, were within the standard ranges described for lactating cows (Kaneko et al., 1997). Although Prototheca moriformis has been associated with udder infection in cows (Buzzini et al., 2004), it is not expected that ALG supplementation will cause mastitis because the microalgae is completely inactivated. As part of the production process, the microalgae is heat treated then dried and pelletized, thus the ALG contains no live organisms. Additionally, the actual risk of $P$. moriformis as a causative agent for bovine mastitis was assessed by bovine mastitis experts. Their determination was that protothecal mastitis is a disease of poor farm management and not of environmental presence on dairy farms (R. J. Erskine, Michigan State University, East Lansing, personal communication). In conclusion, addition of microalgae meal in a dairy cow diet at $91.7 \mathrm{~g} / \mathrm{kg}$ of DM in place of ground corn does not alter milk yield and composition, increases NDF and EE intake, has minimal effects on nutrient digestibility, and increases blood cholesterol.

\section{ACKNOWLEDGMENTS}

Authors are grateful to the Dairy Cattle Research Laboratory of University of Sao Paulo for staff and physical structure necessary for this experiment.

\section{REFERENCES}

AOAC International. 2000. Official Methods of Analysis, 17th ed. AOAC Int., Arlington, VA.

Becker, W. 2004. Microalgae in human and animal nutrition. Pages 312-351 in Handbook of Microalgal Culture. A. Richmond, ed. Blackwell Publishing Ltd, Oxford, UK.
Buzzini, P., B. Turchetti, R. Facelli, R. Baudino, F. Cavarero, L. Mattalia, P. Mosso, and A. Martini. 2004. First large-scale isolation of Prototheca zopfii from milk produced by dairy hers in Italy. Mycopathologia 158:427-430.

Casali, A. O., E. Detmann, and S. C. Valadares Filho. 2008. Influência do tempo de incubação e do tamanho de partículas sobre os teores de compostosindigestíveis em alimentos e fezes bovinas obtidos por procedimentos in situ. Rev. Bras. Zootec. 37:335-342.

Franklin, S. T., K. R. Martin, R. J. Baer, D. J. Schingoethe, and A. R. Hippen. 1999. Dietary marine algae (Schizochytrium sp.) increases concentrations of conjugated linoleic, docosahexaenoic and transvaccenic acids in milk of dairy cows. J. Nutr. 129:2048-2054.

Grummer, R. R., and D. J. Carroll. 1988. A review of lipoprotein cholesterol metabolism: Importance to ovarian function. J. Anim. Sci. 66:3160-3173.

Hall, M. B. 2000. Calculation of non-structural carbohydrate content of feeds that contain non-protein nitrogen. University of Florida, A-25 (Bulletin 339).

Ipharraguerre, I. R., and J. H. Clark. 2003. Review: Soyhulls for dairy cows. J. Dairy Sci. 86:1052-1073.

Ipharraguerre, I. R., R. R. Ipharraguerre, and J. H. Clark. 2002. Performance of lactating dairy cows fed varying amounts of soyhulls as a replacement for corn grain. J. Dairy Sci. 85:2905-2912.

Kaneko, J. J., J. W. Harvey, and M. Bruss. 1997. Appendices. Pages 885-905 in Clinical Biochemistry of Domestic Animals. 5th ed. J. J. Kaneko, J. W. Harvey, and M. Bruss, ed. Academic Press, San Diego, CA.

Kenward, M. G., and J. H. Roger. 1997. Small sample inference for fixed effects from restricted maximum likelihood. Biometrics 53:983-997.

Moate, P. J., S. R. O. Williams, M. C. Hannah, R. J. Eckard, M. J. Auldist, B. E. Ribauz, J. L. Jacobs, and W. J. Wales. 2013. Effects of feeding algal meal high in docosahexaenoic acid in feed intake, milk production and methane emissions in dairy cows. J. Dairy Sci. 96:3177-3188.

Noble, R. C. 1981. Digestion, transport and absorption of lipids. Pages 57-93 in Lipid Metabolism in Ruminant Animals. W. W. Christie, ed. Pergamon Press Ltd., Oxford, UK.

NRC. 2001. Nutrient Requirements of Dairy Cattle. 7th ed. National Academic Press, Washington, DC.

Puppione, D. L., S. T. Kunitake, M. L. Tommey, E. Loh, and V. W. Schumaker. 1982. Physicochemical characterization of ten fractions of bovine alphalipoproteins. J. Lipid Res. 23:371-379.

Sklan, D., R. Ashkennazi, A. Braun, A. Devorin, and K. Tabori. 1992. Fatty acids, calcium soaps of fatty acids, and cottonseeds fed to high yielding cows. J. Dairy Sci. 75:2463-2472.

Stokes, R. S., M. L. Van Emom, D. D. Loy, and S. L. Hansen. 2015. Assessment of algae meal as a ruminant feedstuff: Nutrient digestibility in sheep as a model species. J. Anim. Sci. 93:5386-5394.

Van Emon, M. L., D. D. Loy, and S. L. Hansen. 2015. Determining the preference, in vitro digestibility, in situ disappearance, and grower period performance of steers fed a novel algae meal derived from heterotrophic microalgae. J. Anim. Sci. 93:3121-3129.

Van Soest, P. J., J. B. Robertson, and B. A. Lewis. 1991. Methods for dietary fiber neutral detergent fiber, and non-starch polysaccharides in relation to animal nutrition. J. Dairy Sci. 74:3583-3597.

Westcott, P., and R. Trostle. 2014. USDA agriculture projections to 2023. Accessed Jun. 1, 2015. http://www.ers.usda. gov/ publications/oce-usda-agriculturalprojections/oce141.aspx\#. U8bdnLEXCAQ.

Wu, Z., O. A. Ohajuruka, and D. L. Palmquist. 1991. Ruminal synthesis biohydrogenation, and digestibility of fatty acids by dairy cows. J. Dairy Sci. 74:3025-3034. 